\title{
POWIAT BIAŁOSTOCKI W STOSUNKACH MIĘDZYNARODOWYCH ${ }^{314}$
}

Jednostka samorządu terytorialnego (dalej j.s.t.), jaką stanowi powiat, powstała na mocy ustawy z dnia 5 czerwca 1998 roku, która definiuje go jako lokalną wspólnotę samorządową tworzoną przez mieszkańców oraz określone terytorium. ${ }^{315}$ Upoważnienie do utworzenia innych j.s.t. niż gmina zawiera artykuł 164 Konstytucji Rzeczpospolitej Polskiej. ${ }^{316}$ Granice terytorialne powiatów oraz określenie miast na prawach powiatu ustalone zostały w rozporządzeniu rady ministrów. ${ }^{317}$ Przepisy przejściowe związane z koniecznością przeprowadzenia reformy administracji publicznej zostały uregulowane przez ustawodawcę $\mathrm{w}$ drodze ustawy. ${ }^{318} \mathrm{~W}$ określaniu roli i funkcji powiatu istotny jest fakt, iż samorząd terytorialny w Polsce nie ma charakteru hierarchicznego, co skutkuje pełną autonomią j.s.t. oraz niezależnością i samodzielnością ${ }^{319}$ Ustrój samorządu terytorialnego oprócz Konstytucji RP gwarantuje Europejska Karta Samorządu Lokalnego z 1985 roku. ${ }^{320}$

Ustawa zasadnicza w artykule 172 legitymizuje współpracę międzynarodową j.s.t., a zatem także powiatów, a zasady tej kooperacji ustanowić mają odrębne ustawy. ${ }^{321}$ Jednym $\mathrm{z}$ aktów prawnych o charakterze generalnym, które wprost określają zasady współpracy międzynarodowej j.s.t. jest ustawa o zasadach przystępowania jednostek samorządu terytorialnego do międzynarodowych zrzeszeń społeczności lokalnych i regionalnych z 15 czerwca 2000 roku. ${ }^{322}$ Określa ona warunki przystę-

Student Wydziału Prawa UwB, przewodniczący Parlamentu Studenckiego UwB. Wiceprezes Koła Naukowego Prawa Zarządzania Funduszami Europejskimi, uczestnik proseminarium z prawa międzynarodowego publicznego

Artykuł z założenia odnosi się do praktyki. Zagadnienia teoretyczne związane ze współpracą międzynarodową powiatów omówione zostaną skrótowo, ponieważ owa materia stanowi przedmiot rozważań poprzedniego artykułu w niniejszej publikacji.

Tekst jednolity - Dz.U. z 2001 r. Nr 142, poz.1592 z późn. zm.

Tekst jednolity - Dz.U. z 1997 r. Nr 78, poz. 483 z późn. zm.

Rozporządzenie Rady Ministrów - Dz.U. z 1998 r. Nr 103, poz. 652.

Tekst jednolity - Dz.U. z 1998 r. Nr 133, poz. 872 z późn. zm.

Por. M. Grzybowski, Prawo konstytucyjne, Białystok 2008, s. 290.

Tekst jednolity - Dz.U. z 1994 r. Nr 124, poz. 607.

Tekst jednolity - Dz.U. z 1997 r. Nr 78, poz. 483 z późn. zm.

Tekst jednolity - Dz.U. z 2000 r. Nr 91, poz. 1009 z późn. zm. 
powania jednostek samorządu terytorialnego do międzynarodowych zrzeszeń społeczności lokalnych i regionalnych, a jej stosowanie związane jest z treścią artykułu 75 a ustawy o samorządzie powiatowym, który to przepis odsyła do jej stosowania. ${ }^{323}$

Po ogólnej analizie aktów normatywnych stanowiących bezpośrednio lub pośrednio o współpracy międzynarodowej powiatów należy skupić się na zakresie owej współpracy. Ustawa o samorządzie powiatowym określa szereg zadań publicznych nałożonych na powiat, określając przy tym, że jest to katalog otwarty. ${ }^{324}$ W ramach owych zadań należy dokonać klasyfikacji i wyboru elementów, które są szczególnie istotne w kontekście współpracy międzynarodowej. Według mnie, są to następujące obszary: edukacja publiczna, promocja i ochrona zdrowia, wspieranie osób niepełnosprawnych, transport zbiorowy, drogi publiczne, kultura oraz ochrona zabytków i opieka nad zabytkami, kultura fizyczna, turystyka, ochrona środowiska, zwłaszcza przyrody, rolnictwo, leśnictwo, rybactwo śródlądowe, a także promocja powiatu. ${ }^{325}$ Owe potencjalne pola współpracy międzynarodowej nie wykluczają innych zagadnień, ale wydają się być najbardziej racjonalne, co postaram się udowodnić w drugiej części niniejszej pracy.

Kolejnym istotnym elementem, na który należy zwrócić uwage, jest kompetencja organów powiatu do nawiązywania współpracy z podmiotami zagranicznymi. Ustawa o samorządzie powiatowym w artykule 12 pkt. 9a określa, iż to rada powiatu poprzez uchwały podejmuje decyzję na temat nawiązywania współpracy oraz przystępowania do międzynarodowych zrzeszeń społeczności lokalnych. ${ }^{326} \mathrm{Z}$ dualistycznego charakteru samorządu terytorialnego w Polsce wynika fakt, iż zarząd powiatu jest organem wykonawczym w stosunku do uchwał. ${ }^{327}$ Wynika z tego, że zarząd wykonuje uchwały rady powiatu, a przekładając to na praktykę w ramach współpracy międzynarodowej, odpowiada on za tę współpracę. Jest to alternatywny mechanizm nawiązywania i prowadzenia współpracy międzynarodowej do wcześniej omawianego. Wydaje się, że jest on znacznie prostszy i wymaga spełnienia mniejszej liczby kryteriów formalnych do spełnienia.

\section{Teoria a praktyka}

Rozważania teoretyczne nad zdolnością i rozmaitymi możliwościami aktywności międzynarodowej jednostek samorządu terytorialnego (w tym przypadku powiatów) stwarzają podstawę do analizy tego zagadnienia na konkretnym przykładzie. Obiektem rozważań w tej części pracy będzie powiat białostocki ziemski (zwany

323 Tekst jednolity - Dz.U. z 2001 r. Nr 142, poz.1592 z późn. zm.

324 Ibidem.

325 Ibidem.

326 Ibidem.

327 Por. M. Grzybowski, Prawo konstytucyjne, Białystok 2008, s. 302. 
dalej powiatem). Determinantami, które legitymizują ów wybór, są przede wszystkim: położenie geograficzne, zasięg terytorialny oraz zasoby naturalne i kulturowe. Przy analizie nie można zapominać o fakcie, iż w samym środku powiatu znajduje się miasto Białystok - miasto na prawach powiatu. ${ }^{328} \mathrm{~A}$ zatem należy poruszyć także kwestie związane z dominacją Białegostoku we współpracy zagranicznej - gospodarczej, turystycznej oraz kulturowej, co może się przyczyniać do zmniejszenia roli powiatu ziemskiego, który stanowi otoczenie stolicy województwa podlaskiego. Zbadanie większej liczby powiatów oraz konstatacja wniosków z analizy porównawczej może stanowić temat rozważań na potrzeby odrębnej publikacji, dlatego kwestie te nie zostaną tutaj szerzej omówione.

\section{Powiat białostocki - charakterystyka}

Zasięg terytorialny powiatu obejmuje gminy: Choroszcz, Czarna Białostocka, Dobrzyniewo Kościelne, Gródek, Juchnowiec Kościelny, Łapy, Michałowo, Poświętne, Supraśl, Suraż, Turośń Kościelna, Tykocin, Wasilków, Zabłudów, Zawady. ${ }^{329}$ Zajmuje on ogólną powierzchnię 297600 ha, z czego 121124 ha to lasy i grunty leśne. ${ }^{330}$ Przez teren powiatu przebiegają następujące szlaki komunikacyjne:

- droga krajowa nr 18 Białystok-Sokółka-Kuźnica Białostocka,

- droga krajowa nr 19 Białystok-Augustów-Ogrodniki (przejście graniczne z Litwą),

- droga krajowa nr 66 Białystok-Bobrowniki (przejście graniczne z Białorusią) - linia kolejowa Warszawa-Grodno-Wilno-Sankt Petersburg.

Na koniec 2011 roku liczba ludności zamieszkującej powiat o powierzchni $2976 \mathrm{~km}^{2}$ wynosiła 143701 osób, a więc gęstość zaludnienia wynosiła około 48 osób na $\mathrm{km}^{2} .331$

Powyższe dane ukazują specyfikę powiatu w ogólny sposób. Natomiast rozważenie konkretnych przykładów działań w sferze współpracy międzynarodowej należy poprzedzić analizą SWOT, która pozwoli ustalić szczególnie pożądane pola omawianej aktywności powiatu.

328 Rozporządzenie Rady Ministrów z dnia 7 sierpnia 1998 r. w sprawie utworzenia powiatów - Dz.U. z 10.08.1998 roku Nr 103, poz. 652.

329 Ibidem.

330 Strategia Rozwoju Powiatu Białostockiego na lata 2011-2020, tryb dostępu: http://www.powiatbialostocki.pl/powiat/strategia-rozwoju/, dnia 14.12.2012 r.

331 Rocznik Demograficzny 2012, tryb dostępu: http://www.stat.gov.pl/gus/5840_rocznik_demograficzny_PLK_ HTML.htm, dnia 14.12.2012 r. 
Tabela 2. Analiza SWOT uwarunkowań rozwojowych powiatu białostockiego

\begin{tabular}{|c|c|}
\hline $\begin{array}{l}\text { MOCNE STRONY } \\
\text { - strategiczne położenie geopolityczne } \\
\text { w sąsiedztwie } 2 \text { państw } \\
\text { - przebieg przez powiat komunikacyjnych tras } \\
\text { tranzytowych } \\
\text { - potencjał zasobów naturalnych - park narodowy, } \\
\text { parki krajobrazowe, rezerwaty }\end{array}$ & $\begin{array}{l}\text { SŁABE STRONY } \\
\text { - niedoinwestowanie usługowe i infrastrukturalne } \\
\text { większości terenów wiejskich i małych miast, } \\
\text { - niski poziom rozwoju gospodarczego wynikający } \\
\text { z niedoinwestowania, } \\
\text { - wysoka stopa bezrobocia, szczególnie } \\
\text { na terenach wiejskich }\end{array}$ \\
\hline $\begin{array}{l}\text { SZANSE } \\
\text { - możliwość rozwoju współpracy transgranicznej } \\
\text { - wzrost znaczenia środowiska przyrodniczego } \\
\text { do rozwoju turystyki, wypoczynku, lecznictwa } \\
\text { uzdrowiskowego } \\
\text { - powiat białostocki jako składnik Aglomeracji } \\
\text { Białostockiej }\end{array}$ & $\begin{array}{l}\text { ZAGROŻENIA } \\
\text { - niski standard istniejących dróg i szlaków } \\
\text { kolejowych } \\
\text { - niska atrakcyjność inwestycyjna } \\
\text { - miasto Białystok jako główny partner } \\
\text { we współpracy międzynarodowej dla } \\
\text { potencjalnych partnerów }\end{array}$ \\
\hline
\end{tabular}

Źródto: Strategia Rozwoju Powiatu Bialostockiego na lata 2011-2020, s. $4 .{ }^{332}$

Na podstawie powyższych rozważań można stwierdzić, że obszarami priorytetowymi współpracy międzynarodowej powiatu białostockiego są: transgraniczność, środowisko przyrodnicze, turystyka, edukacja oraz kultura, co zostało potwierdzone w Strategii Rozwoju Powiatu Białostockiego na lata 2011-2020. ${ }^{333}$

Konstatacja powyższych danych oraz ich interpretacja ipso facto stanowią podstawę do analizy konkretnych przykładów aktywności powiatu we współpracy międzynarodowej. W działalności omawianego powiatu reprezentowanego przez odpowiednie władze można, co prawda, zauważyć zaangażowanie we współpracę międzynarodową. Nigdy jednak nie podjęto próby przystąpienia do międzynarodowych zrzeszeń społeczności lokalnych lub regionalnych, gdyż władze skupiały się na realizacji doraźnych zobowiązań wynikających z umów partnerskich z konkretnymi podmiotami. ${ }^{334}$ Jest to na ogół kooperacja $\mathrm{z}$ wyodrębnionymi jednostkami terytorialnymi państw obcych oraz stowarzyszeniami z innych krajów.

Starostwo Powiatowe w Białymstoku nie ma wyodrębnionego wydziału, który zajmowałby się współpracą międzynarodową. ${ }^{335}$ Działania te podejmowane są przez istniejące wydziały, w szczególności: rolnictwa, środowiska, rozwoju obszarów wiejskich, promocji oraz spraw społecznych. ${ }^{336}$ Kwalifikacje językowe kadry urzęd- 
niczej powiatu odpowiadają wymogom problematyki, czyli pracownicy władają językami obcymi na poziomie komunikatywnym w mowie i piśmie (głównie język angielski), ale zauważyć należy, że władze powiatu korzystają dodatkowo z usług tłumaczy współpracujących ze starostwem podczas oficjalnych spotkań lub inicjatyw, które tego wymagają. ${ }^{37}$ Pracownicy ulepszają swoje kwalifikacje językowe poprzez kontakt z wolontariuszami odbywającymi praktyki w Starostwie, którzy pochodzą z wielu państw, np. Hiszpanii, Włoch, Francji, Turcji. ${ }^{338}$ Jest to przejaw współdziałania od 2003 roku z organizacją AIESEC, gdyż studenci zagraniczni poznają specyfikę samorządu terytorialnego w Polsce, a urzędnicy mogą poznawać ich kulturę, obyczaje oraz konwersować z nimi w języku angielskim. ${ }^{339}$ Można stwierdzić, że daje się zauważyć organizacyjny duży potencjał w działaniu na rzecz współpracy międzynarodowej powiatu. Aby oszacować jego wykorzystanie należy zbadać konkretne, wybrane przedsięwzięcia przedmiotowe i poddać je analizie.

Pierwszym przejawem współpracy międzynarodowej powiatu są porozumienia podpisane za zgodą Rady Powiatu z następującymi podmiotami:

- Województwo Grodzieńskie - Białoruś,

- Województwo Alituskie - Litwa,

- Samorząd Druskienniki - Litwa. ${ }^{340}$

Porozumienia te miały stanowić podłoże do potencjalnej współpracy, a nie konkretnych celów, które powinny osiągnąć. Można uznać, że owe działania spełniły raczej rolę budowania strategii rozwoju opartej o nawiązywanie kontaktów z potencjalnymi partnerami na wypadek ewentualnej realizacji przyszłych przedsięwzięć. Są one również swego rodzaju wymianą doświadczeń, z których władze powiatu mogą czerpać wiele korzyści, przekładać pozytywne wzorce oraz stanowić podstawę do transferu wiedzy. Nie można mówić zatem o wymiernych korzyściach oprócz kreowania kurtuazyjnych kontaktów i przygotowywania przyjaznego podłoża współpracy na przyszłość. Tworzyły one raczej bazę do organizowania wspólnych konferencji, seminariów, wyjazdów studyjnych oraz transferu wiedzy i doświadczen. ${ }^{341}$ Oczywiście należy ocenić pozytywnie takie działania, a szczególnie zainteresowanie współpracą z podmiotami zza wschodnich granic Polski. Niestety, obecnie na kanwach wymienionych porozumień z 2004 roku nie są prowadzone żadne działania.

Współpraca powiatu z Prowincją di Reggio Calabria została zawarta na mocy porozumienia z 1 kwietnia 2004 roku. Uzgodniono tam, że powiat białostocki będzie

337 Ibidem.

338 Ibidem.

339 Ibidem.

340 Uchwały Rady Powiatu nr XV/123/2004, XV/124/2004, XV/125/2004, tryb dostępu: http://bip.st.bialystok.wrotapodlasia.pl/Rada_Pow/Rp_ProgDzia/94895c57f13aa99/?pid=P_Miedzynar, dnia 14.12.2012 r. oraz Wywiad z Jolantą Den..., op. cit. 
partnerem strony włoskiej w projekcie składanym do Komisji Europejskiej (zwaną dalej KE) w ramach programu Town Twinning pod nazwą: , Wyroby rzemieślnicze pomostem integracji kulturowej i ekonomicznej między krajami Unii Europejskiej”, który został zaakceptowany przez KE do realizacji. Realizacja polegała na wyjazdach studyjnych, konferencjach oraz warsztatach. Warto nadmienić, że inicjatorem zawarcia porozumienia była strona włoska.

Kolejnym przykładem aktywności analizowanego powiatu w stosunkach międzynarodowych jest podpisanie 10 maja 2007 roku „Porozumienia - Deklaracji Wspótpracy" ze Stowarzyszeniem Lwa, którego siedzibą jest miasto Lwów. ${ }^{342}$ Działanie to miało podstawę w dążeniu do uzyskania środków z Programu Sąsiedztwa Interreg III A Polska - Białoruś - Ukraina na realizację projektu: „,Rozwój transgranicznych funkcji Regionalnego Centrum Kształcenia w zakresie Turystyki Aktywnej w Supraślu. Polsko - Biatorusko - Ukraińskie targi turystyczne. Wsparcie bazy sportowo - dydaktycznej". Porozumienie było niezbędne do złożenia wniosku, gdyż powiat stanowił jedyne przedstawicielstwo wnioskodawców wobec Unii Europejskiej. Inicjatywa ta została zrealizowana. Obecnie brak jest przejawów współpracy pomiędzy omawianymi podmiotami. Porozumienie miało charakter zadaniowy i rzeczywiście spełniło rolę elementu wzmacniającego szansę podmiotów na skuteczną realizację projektu.

Zarząd powiatu został upoważniony przez radę powiatu do nawiązania współpracy oraz podpisania umowy partnerskiej z samorządem Kalwarii na Litwie. ${ }^{343}$ Podstawą do tego upoważnienia był zamiar ubiegania się o dofinansowanie projektu „Otwarcie terenów inwestycyjnych przy korytarzu międzynarodowym E67 PolskaLitwa". Trudno tu o szczegółową analizę, ponieważ w archiwum Starostwa Powiatowego w Białymstoku brak jest jakichkolwiek informacji o realizacji omawianej uchwały rady powiatu. Jednak można skonstatować, że władze powiatu aktywnie starały się wykorzystać atrakcyjne położenie w odniesieniu do atrakcyjnych komunikacyjnie tras tranzytowych przebiegających przez powiat.

W 2009 roku powiat nawiązał współpracę z Gromadską Organizacją „Kiwierciwskij Biznes - Inkubator Wolyńskiego Instytutu Ekonomiki Ta Menedźmentu Kiwierci, Wolyńska Obłast” (GO „KBI WIEM”) z Ukrainy. Dnia 16 grudnia podpisano protokół w sprawie podjęcia współpracy, który zobowiązał strony do zawarcia deklaracji o współpracy. ${ }^{344}$ Analizie należy poddać logikę takiego postępowania. Wspomniane podmioty w protokole z grudnia 2009 roku zawarly także porozumienia w sprawie realizacji konkretnych projektów w ramach Współpracy Transgranicznej Polska - Białoruś - Ukraina 2007-2013. Protokół miał na celu zagwa-

342 Uchwała Rady Powiatu nr XV/122/2004, tryb dostępu: http://bip.st.bialystok.wrotapodlasia.pl/Rada_Pow/Rp_ ProgDzia/94895c57f13aa99/?pid=P_Miedzynar, dnia 14.12.2012 r. roku oraz Wywiad z Jolantą Den..., op. cit.

343 Uchwała Rady Powiatu nr XX/195/08, tryb dostępu: http://bip.st.bialystok.wrotapodlasia.pl, dnia: 14.12.2012 r.

344 Protokół w sprawie podjęcia współpracy z dnia 16.12.2009 r., zasoby własne Starostwa Powiatowego w Białymstoku. 
rantowanie pewności stanowisk obydwu stron oraz stanowił podstawę realizacji wspólnych działań. W efekcie rada powiatu w styczniu 2010 roku wyraziła zgodę na podjęcie współpracy ze wspomnianym ukraińskim partnerem. ${ }^{345}$ Deklaracja została podpisana na użytek konkretnego projektu pod nazwą ,,Stworzenie Ukraińsko - Polskiego Centrum Kształcenia Instruktorów Turystyki Konnej”. ${ }^{346}$ W 2008 roku zorganizowano targi turystyczne „Bukowisko” w ramach projektu pt. „Rozwój transgranicznych funkcji Regionalnego Centrum Ksztatcenia w Zakresie Turystyki Aktywnej w Supraślu. Polsko-Białorusko-Ukraińskie targi turystyczne. Wsparcie bazy sportowo-dydaktycznej", ${ }^{347}$ współfinansowanego ze środków Europejskiego Funduszu Rozwoju Regionalnego w ramach Programu Sąsiedztwa Polska-Białoruś-Ukraina Interreg III A/ Tacis CBC 2004-2006. W 2010 roku złożono zaś wniosek pn. „Utworzenie ukraińsko-polskich centrów turystyki ekologicznej w narodowych i krajobrazowych parkach przyrodniczych Wotynia i Podlasia" w ramach Programu Współpracy Transgranicznej Polska-Białoruś-Ukraina 2007-2013.

Ostatnim przykładem partnerskiej aktywności międzynarodowej powiatu, na którym należy się skupić, jest współpraca z regionem Pays de la Bresse Bourguignonne. Jest to przykład stałej kooperacji, gdyż podmioty realizują wspólnie projekty od 2004 roku. ${ }^{348} \mathrm{~W}$ ramach współpracy podpisano porozumienie oraz deklarację, które są każdorazowo zawierane na potrzeby nowych, wspólnych projektów. Należy stwierdzić, iż owa współpraca ma charakter dynamiczny, efektywny ponieważ nieprzerwanie od 2004 roku rodzi ona wiele inicjatyw i realnych przedsięwzięć. Od momentu nawiązania współpracy podmiotom udało się zrealizować w powiecie następujące projekty:

- budowę krytej ujeżdżalni koni w Supraślu w ramach Zintegrowanego Programu Operacyjnego Rozwoju Regionalnego 2004-2006, nazwa projektu: „Regionalne Centrum Ksztatcenia w Zakresie Turystyki Aktywnej”,

- wyposażenie ośrodka „Bukowisko” w sprzęt sportowy w ramach Programu Rozwoju Obszarów Wiejskich na lata 2007-2013, nazwa projektu: „,Rozwój turystyki aktywnej na terenie Puszczy Knyszyńskiej - turystyka kajakowa”,

- opracowanie i wydanie materiałów promocyjnych powiatu białostockiego w języku polskim, francuskim i angielskim (mapę powiatu białostockiego, mapki tematyczne: szlaki konne, kajakowe, piesze i rowerowe, przewodnik turystyczny oraz folder promocyjny) w ramach projektu: „Promowanie rozwoju turystyki $w$ powiecie biatostockim $w$ oparciu o dobre praktyki francuskie” współfinansowanego w ramach Programu „Fundusz Wsparcia 
Inicjatyw Lokalnych, Międzynarodowych i Transgranicznych w Euroregionie Niemen. ${ }^{349}$ Powiat jest członkiem Stowarzyszenia Euroregion Niemen. ${ }^{350}$

Na przełomie kwietnia i maja 2012 roku powiat gościł partnerów z Pays de la Bresse Bourguignonne, co było podsumowaniem długoletniej współpracy w dziedzinie turystyki. Warto podkreślić, że jest to najbardziej aktywny i priorytetowy partner, gdyż działania podejmowanie są nieprzerwanie od 2004 roku, a na potrzeby kooperacji strona internetowa powiatu białostockiego dostępna jest także w języku francuskim. ${ }^{351}$

\section{Wnioski}

\section{Status quo}

Konstatując powyższe rozważania, należy stwierdzić, iż omawiany powiat aktywnie udziela się w aspekcie współpracy międzynarodowej. Liczne porozumienia i deklaracje stwarzają pozytywne przesłanki do realizowania konkretnych działań, ale ich analiza rodzi pytanie o cel tych działań. Opierając się na dostarczonych przykładach teoretycznych i praktycznych, można skonstatować, iż mamy tu do czynienia $\mathrm{z}$ dychotomicznym podziałem powodów nawiązywania kontaktów międzynarodowych.

Pierwszą kategorią są porozumienia ukierunkowane na realizację konkretnych projektów, co jest niezbędne przy ubieganiu się o środki finansowe na realizację określonych przedsięwzięć. Wydaje się, że jest to mocno legitymizowane logicznie działanie, gdyż nie dochodzi tu do działań fikcyjnych, które oprócz korzystnych statystyk dla władz, nic nie wnoszą.

Drugą kategorią są działania zorientowane na współpracę jako wartość samą w sobie. W tym przypadku współpraca międzynarodowa jest wynikiem dążenia do budowy strategii kreowania przyjaznych relacji z podmiotami pochodzącymi z innych państw. Władze powiatu często starają się pozyskiwać partnerów, aby strategicznie zabezpieczyć się w tym względzie pod kątem realizacji przedsięwzięć, które mogą pojawić się w przyszłości. Jest to przejaw prestiżu oraz kurtuazji w aspekcie międzynarodowym. Wydawałoby się, że taka praktyka nie niesie za sobą efektów, jednak byłby to spłycony wniosek. Już bowiem sama współpraca rodzi wiele pozytywnych skutków: wzajemne poznanie podmiotów, organizację konferencji, seminariów, lobby wspólnych priorytetów na arenie międzynarodowej. Jednak niezbędnym elementem skonkretyzowanej (później) współpracy jest ukształtowanie

349 Wywiad z Jolantą Den..., op. cit.

350 Tryb dostępu: http://www.stat.gov.pl/cps/rde/xbcr/wroc/ASSETS_145-164.pdf, dnia 14.12.2012 r.

351 Tryb dostępu: http://www.powiatbialostocki.pl/le-powiat/, dnia 14.12.2012 r. 
wspólnej podstawy aksjologicznej, która stanowi spoiwo kooperacji oraz wyznacza jej cele.

Kolejną cechą, która determinuje dychotomiczny podział aktywności powiatów we współpracy międzynarodowej jest ich pozycja przy nawiązywaniu kontaktów z innymi podmiotami. Podział opiera się na kryterium samodzielności działań, jakie mogą podejmować władze w imieniu powiatu. Działania bezpośrednie to te, w których powiat występuje jako autonomiczny podmiot w stosunkach $\mathrm{z}$ określonymi partnerami, czyli jest jedną ze stron stosunku współpracy. A contrario - działania pośrednie mogą być wykonywane poprzez pośrednika. Przykładem takiego przedstawiciela jest Związek Powiatów Polskich (zwany dalej ZPP), do którego należy omawiany powiat. ${ }^{352}$ Statut ZPP jasno wskazuje kompetencję do nawiązywania współpracy międzynarodowej z jednostkami samorządu terytorialnego innych państw oraz umożliwia bycie członkiem organizacji o podobnym celu działania. ${ }^{353}$

\section{De lege ferenda}

Po diagnozie stanu obecnego pojawia się wyzwanie, by podjąć próbę wskazania rozwiązań, które mogą okazać się użyteczne w przyszłości. Już sama analiza teoretyczna zdolności powiatów do współpracy międzynarodowej rodzi wiele pytań. Czy wystarczające są obecne instrumenty prawne, w które wyposażone są władze powiatu do swobodnego kreowania pozycji powiatu we współpracy międzynarodowej? Jaka powinna być istota zawieranych porozumień? Czy o skuteczności stanowić ma kryterium ilości, a może jakość i efektywność?

Jak wskazują praktycy omawianej współpracy [tu patrz np.: obecne władze powiatu białostockiego], obecne kompetencje są wystarczające do kreowania dynamicznych i efektywnych stosunków z partnerami. ${ }^{354}$ Władze powiatu białostockiego, np. nigdy nie wykorzystywały formuły przewidzianej ustawą o zasadach przystępowania jednostek samorządu terytorialnego do międzynarodowych zrzeszeń społeczności lokalnych i regionalnych, która ustala sformalizowaną procedurę podejmowania współpracy międzynarodowej jednostek samorządu terytorialnego. ${ }^{355}$ Praktyka odchodzi od stosowania owej ustawy i wybierane są mniej sformalizowane formy kooperacji. ${ }^{356}$ Deficyt, który może być szczególnie odczuwalny, to brak wyspecjalizowanego wydziału w starostwach, który zajmowałby się współpracą międzynarodową. Stworzyłoby to możliwość unifikacji działań oraz zaplecza dla profesjonalnego podejścia. Oczywiście braki te nie są w większości spowodowane zaniedbaniem władz, ale oszczędnościami w funkcjonowaniu starostw. Elementem, który mógłby wzmocnić partycypację powiatów w aspekcie współpracy

352 Więcej na: http://www.zpp.pl, stan na: 14.12.2012 r.

353 Tryb dostępu: http://www.zpp.pl/dokumenty/statut 2011.pdf, dnia 14.12.2012 r.

354 Wywiad z Jolantą Den..., op. cit.

355 Tekst jednolity - Dz.U. z 2000 r. Nr 91, poz. 1009 z późn. zm.

356 Wywiad z Jolantą Den..., op. cit. 
międzynarodowej, są szkolenia z zakresu poprawiania kompetencji językowych, protokołu dyplomatycznego, autoprezentacji czy też argumentacji. Odpowiadając na pytanie „ilość czy jakość” wniosek nasuwa się automatycznie: synergia działań w realizacji obu wartości. Ilość nie przeszkadza jakości, a przeciwnie - może wpłynąć na jej zwiększenie, ponieważ współpraca może przynieść wiele wymiernych korzyści, których często nie sposób rozważać w kontekście finansowym. Władze powiatów nie mogą zapominać o angażowaniu się w działalność organizacji międzynarodowych, np. euroregionów czy międzynarodowych stowarzyszeń, ponieważ jest to bardzo użyteczny instrument do nawiązywania kontaktów bilateralnych. Samorządy powiatowe powinny także szukać możliwości realizacji swoich zadań poprzez współpracę z organizacjami pozarządowymi, które mają już partnerów zagranicznych, a często brakuje im środków na realizację projektów.

Podsumowując, należy stwierdzić, że aktywność powiatu białostockiego w sferze współpracy międzynarodowej jest znaczna. Wymienione projekty oraz inicjatywy to potwierdzają. Można także zauważyć pewną logikę w działaniu, gdyż znaczna większość projektów realizowanych w ramach współpracy międzynarodowej dotyczy: turystyki, środowiska naturalnego, aspektu transgraniczności oraz edukacji, co świadczy o wykorzystaniu posiadanego przez powiat potencjału. 


\section{BIALYSTOK DISTRICT IN INTERNATIONAL RELATIONS}

The issue of local government has been widely developed by doctrine, following the administrative reform of the Polish Republic in 1998 which established counties. This article analyzes the possibility of international cooperation counties with partners from other countries. Apart from theoretical considerations, which are extremely important and they are the starting point for the article, attention is drawn to the practical aspect of the functioning of this cooperation. The dominant part of the article is to show the mechanisms that are used by the county government to create international cooperation which is made by county. The example of considerations is Bialystok County. The conditions which determine this choice are: geographical location, extent of the territory and its natural and cultural resources, as well as the position of Bialystok - a city with county rights. The author discussed specific projects in the framework of international cooperation and the practical aspects of it. Application also generates many problems and creates the basis for a broader analysis. Questions that can be formed after consideration relate to the purpose of international cooperation, the independence of counties in it's implementation and the mechanisms that can improve and strengthen it. The author discusses all of these issues and creates a comprehensive picture of the possible changes that may contribute to increasing the efficiency and quality of activities undertaken by the counties within the framework of international cooperation.

Keywords:

County, international cooperation, internationalization of counties 